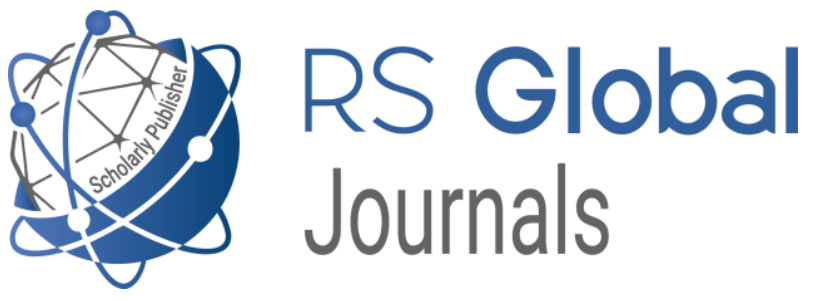

Scholarly Publisher

RS Global Sp. z O.O.

ISNI: 0000000484952390

Dolna 17, Warsaw, Poland 00-773

Tel: +48226022703

Email: editorial_office@rsglobal.pl

JOURNAL International Journal of Innovative Technologies in Social Science

p-ISSN

$2544-9338$

e-ISSN

2544-9435

PUBLISHER

RS Global Sp. z O.O., Poland

ARTICLE TITLE

LINGUISTIC COMPETENCE AS AN IMPORTANT COMPONENT OF TEACHING ACTIVE METHODS IN READING

$\operatorname{AUTHOR}(\mathbf{S})$

Svitlana Rubtsova

Svitlana Rubtsova. (2021) Linguistic Competence as An

ARTICLE INFO Important Component of Teaching Active Methods in Reading. International Journal of Innovative Technologies in Social Science. 1(29). doi: 10.31435/rsglobal_ijitss/30032021/7452

DOI https://doi.org/10.31435/rsglobal_ijitss/30032021/7452

RECEIVED

16 December 2020

ACCEPTED

10 February 2021

PUBLISHED

15 February 2021

LICENSE

This work is licensed under a Creative Commons Attribution

4.0 International License.

(C) The author(s) 2021. This publication is an open access article. 


\title{
LINGUISTIC COMPETENCE AS AN IMPORTANT COMPONENT OF TEACHING ACTIVE METHODS IN READING
}

\author{
Svitlana Rubtsova, Docent, Kyiv National University of Construction and Architecture, Kyiv, \\ Ukraine, ORCID ID: https://orcid.org/0000-0003-4114-5874
}

DOI: https://doi.org/10.31435/rsglobal_ijitss/30032021/7452

\section{ARTICLE INFO}

Received 16 December 2020

Accepted 10 February 2021

Published 15 February 2021

\section{KEYWORDS}

linguistic competence, active methods of education, English for specific purposes (ESP), methods of active reading, KWL and SQ3R methods of reading, authentic visualization of educational information (AVEI)

\begin{abstract}
The article deals with the applying of active methods in reading and the formation of linguistic competence for teaching English for specific purposes (ESP) to future bachelors in the field of Civil Engineering.

Purpose of the research is to describe linguistic competence as an important component of the process of teaching active methods in reading to future engineers, to define some active methods in reading that can be implemented in the teaching of ESP in the process of training future civil engineers.

Methods. Reviewing the studies on linguistic competence in reading in the process of teaching ESP and methods of active reading.

Results. Prospects for teaching methods of active reading (KWL and SQ3R) to future engineers in the ESP teaching process are described. The definition of lexical competence and its components in the process of teaching methods of active reading is given. The difficulties of teaching active reading in ESP for students of technical specialties are determined.

Conclusion. Taking into account that creativity and active participation are important factors in motivating students to learn ESP, we consider it appropriate to use methods of active reading (KWL and SQ3R) in combination with other intensive methods and technologies to train future engineers. We believe that exercises and tasks with different forms and models of authentic visualization of educational information (AVEI) for learning English vocabulary in professionally oriented reading are effective. AVEI, taken from professional articles and other authentic materials in the field of civil engineering, can contribute to the formation of lexical competence of students.
\end{abstract}

Citation: Svitlana Rubtsova. (2021) Linguistic Competence as An Important Component of Teaching Active Methods in Reading. International Journal of Innovative Technologies in Social Science. 1(29). doi: 10.31435/rsglobal_ijitss/30032021/7452

Copyright: (C) 2021 Svitlana Rubtsova. This is an open-access article distributed under the terms of the Creative Commons Attribution License (CC BY). The use, distribution or reproduction in other forums is permitted, provided the original author(s) or licensor are credited and that the original publication in this journal is cited, in accordance with accepted academic practice. No use, distribution or reproduction is permitted which does not comply with these terms.

Introduction. The topic of lexical competence, general problems of its formation, methodological potential of its components and issues related to this area were researched by a great number of scholars. Research efforts were aimed at effective foreign language acquisition through active teaching methods. Problems of active teaching methods, in particular those or other components that enhance the educational and cognitive activities of the student in the study of foreign languages were the subject of research by many scholars: R. B. Dilts, T. A. Epstein and K. Vopel (dynamic learning technologies), A. D. Vyselko (immersion method), G. O. Kitaygorodskaya and G. Lozanov (intensive learning technologies), O. O. Parshikova and V. V. Chernysh (communicative game-based learning method), N. F. Borisko and V. V. Safonova (linguosociocultural method), I. Yu. Shekhter (emotional-semantic method) and others.

Research results. The results of the literature review show that scholars consider active teaching methods as those that encourage students to learn and increase students' personal motivation in the learning process [1-5]. 
For our research, we chose the Know-Want-Learn (KWL) method by D. Ogle, (1986) and SQ3R (Survey, Questions, Read, Recall, Review) method by Francis P. Robinson (1978) of reading because these methods are referred to as active learning technologies [6,7]. KWL and SQ3R methods are characterized by encouraging students to cognitive activity in the learning process, focusing on students' needs, involving all participants in the cognitive process of education.

Active reading methods are aimed at the development of abstract and critical thinking and contribute to the analysis and synthesis of new ideas of students in actions in non-standard situations, which is one of the general competencies of future engineers, which is named in the list of general abilities in the Standard of Higher Education of Ukraine for a graduate of the bachelor's level in the field of knowledge Architecture and Construction [8].

Active reading methods are multifunctional, creative for the formation of different learning options and its organization.

KWL method enables:

activate students' knowledge and help focus on the expected material;

learn to predict the content by the title of the text or article,

train guessing the expected information;

consciously perceive the text;

learn to analyze and optimally structure the received new information;

develop your own personal learning strategy by activating a comprehensive experience;

stimulate the search for additional information on the topic;

develop your own personal learning strategy;

organize work for projects or research, collect and organize information (graphic organizer):

rationally consider the topic, focus on the main questions, helps to find answers and outline new directions for finding and solving the problem being studied by the student or researcher [6, 9-11].

The SQ3R method of active reading promotes:

rapid understanding and memorization of information;

students' skills to choose and memorize useful information, outline important questions and

look for answers;

rational and effective learning, mastering the method as a strategy for learning;

self-training of students, which is indicated in the list of general abilities in the Standard of Higher Education of Ukraine for a graduate of the bachelor's level in the field of knowledge Architecture and Construction as the ability to acquire knowledge independently [7, 8, 12-15].

Thus, it is taken into account the fact that the model of active learning is based on creativity and active participation in the learning process of both students and teachers, encouraging the search for new ideas and answers to important questions in the field of Civil Engineering.

We agree with the statement of scholars that knowledge of professional vocabulary is both an important component of the professional growth of students of technical specialties and a complex aspect of learning a foreign language. ESP for the engineers is constantly evolving and changing along with technologies, enriched with new areas with technical terms, abbreviations, neologisms, etc.

The results of the literature review show that scholars define a term "lexical competence" as a person's ability to form statements correctly and understand the speech of others. It involves the complex dynamic interaction of certain skills, knowledge and lexical awareness [16].

We will consider in detail the components of lexical competence and determine which of them can be successfully formed in the process of teaching of active reading. Scholars distinguish two types of lexical skills: receptive and reproductive. Receptive lexical skill is an automated perception and understanding of lexical units in oral and written communication. While, reproductive lexical skill is the automated use of lexical units in oral and written communication.

Receptive lexical skills include:

recognition, differentiation and identification of written forms of lexical units in the teaching of active reading are possible during the performance of pre-text exercises and tasks for acquaintance and mastering of lexical units and during further reading of selected texts;

correlation of lexical units with the corresponding object or phenomenon in a drawing, sketch or graphic is possible when performing pre-text exercises and practical tasks after the text to perform elementary drawing. 
It should be noted that the recognition, differentiation and correlation of oral forms of lexical items are possible in the presence of audio materials or selected video on the topic.

Reproductive lexical skill in written speech in the teaching of active reading is formed during the performance of pre-text exercises, in the process of reading and performing post-text tasks. The process of forming a reproductive lexical skill includes:

recall a lexical item from long-term memory;

reproduction of a lexical unit in internal speech;

combination of lexical units with other words that form a syntagma and a phrase according to the rules of lexical compatibility.

Taken into account the step-by-step process of teaching active reading, which includes stages of reflection and discussion, it is possible to say about the formation of both receptive and reproductive skills during learning.

According to scientists, lexical knowledge is a component of lexical competence that reflects the results of student's knowledge of the lexical system of a foreign language.

We believe that teaching methods of active reading (KWL and SQ3R) in combination with other intensive methods and technologies to train future engineers allow to gain students the following lexical knowledge during the process of learning (pre-reading activities, while-reading stage, after reading activities):

recognition of the written form of terminological lexical units;

understanding the semantics of terminological lexical units;

usage of terminological lexical units at the level of phrase, sentence, text;

connecting value of terminological lexical units;

understanding the rules of word formation;

getting the basic concepts of word structure;

understanding the similarities and differences in the lexical systems of the native language and ESP.

Scholars define "lexical awareness" as one of the components of lexical competence and give the following definition of this concept:

lexical awareness is a component of general language awareness or a conscious approach to the phenomena of language and speech, as well as to one's own mastery of foreign language communicative competence.

Lexical awareness implies the student's ability to:

create a system of their own lexical knowledge knowingly and deliberately; consciously mark, recognize and use lexical units of different levels;

understand the patterns of formation and functioning of lexical units;

be aware of the advantages and disadvantages of their type of "speaker" and "student" in terms of lexical competence;

analyze the lexical side of their speech and draw appropriate conclusions [16].

A review of research on the psychological problems of active learning suggests that the psychological nature of the individual is a very important part of the active learning process. Knowledge of the psychological characteristics of students allows to provide the best approaches for dynamic learning. The formation of lexical competence of English in reading for future engineers who study ESP using active methods can be effective due to the peculiarities of psychological mechanisms and the functioning of the leading representative systems of students.

Leading representative systems that allow the most efficient memorization of new vocabulary units were identified during the testing of civil engineering students. Future engineers had the opportunity to analyze the use of different representative systems and their combinations in memorization, to identify their strengths and weaknesses in the perception and memorization of new vocabulary. This study showed that knowledge of the psychological characteristics and mechanisms of active learning and understanding the importance of involvement leading representative systems of students in the teaching process have a positive effect on understanding and mastering new information in English.

General psychological mechanisms of active learning promote the activation of thinking, development of different types of memory and critical thinking, stimulate the connection of previous experience of students, help future engineers to learn technical terms, enrich vocabulary and understand professional texts. It was found that the understanding of the concept that dynamic learning 
activities should be considered as a previous experience of students, the scope of their professional interests and the functioning of their leading representative systems. All this knowledge provides an effective incentive in the study of ESP in various fields of engineering [4].

The cognitive process in language acquisition in teaching the methods of active reading allow students to understand and analyze the peculiarities of perception and memorization lexical terms and find own strategy in creating personal lexical knowledge by engaging and developing abstract thinking. Support and development of students' creativity and motivation in mastering new lexical material is the main task in teaching of active methods.

When trying to implement active reading methods in the teaching of ESP, certain difficulties at some stages of step-by-step tasks were observed. The main difficulties were related to the lack of knowledge of terminology in the specialty, such as terms, complex terms and their combinations with other words. Difficulties were identified in performing the following tasks were identified.

1. Pre-reading activities:

a) when responding to the questions or writing some questions about the topic (What do you know about the topic? What do you want to know?);

b) while sharing some ideas with other students.

2. While-reading stage:

a) scanning the text,

b) writing some questions about the text.

We know from our own experience that the lack of knowledge of terms makes it impossible to think about a professional topic freely, creatively and productively; at the same time, it is obvious that using a dictionary or learning terms in advance does not promote the creative process, which is a necessary condition for teaching the methods of active reading. In our opinion, pre-text exercises that are organized on the basis of AVEI allow to promote the formation of lexical skills of reading text materials in the field of civil engineering and the creation of a certain system of lexical knowledge of a student.

Under the concept of AVEI we mean conditionally technical visualization of educational information (VEI), which was not artificially created for educational purposes of studying foreign languages, but was developed for additional visual information on the specialty as an accompaniment to textual material for better perception and understanding. It should be noted that we call VEI conditionally technical because such visualization is possible in the form of visual material of different nature, which contributes to better understanding of textual material in field of Civil engineering and complements this material (drawings, photographs, diagrams, charts, graphs, video, etc.) $[17,18]$.

Pre-reading activities encourage students to overcome the difficulties in mastering terminological lexical units, change the direction of learning from routine to creative one. After Pretext exercises students know:

meaning of terminological lexical units,

graphic and sound form of terminological lexical units,

compatibility of different terminological lexical units. This is especially important when combining terms or complex terms in phrases that do not have an exact structural and semantic equivalent in the native language.

It should be noted that students can successfully perform exercises based on AVEI both classroom and extracurricular.

Conclusions. It should be noted that knowledge of terms on a particular topic in the consideration and reflection of students is an important component in the process of teaching the methods of active reading. In our opinion, the usual studying of professional terms before the process of creative thinking or using a dictionary during the process can solve the problem of knowing professional vocabulary but at the same time can reduce the process of students' creativity when thinking about the title of the article and the questions that interest students on the topic.

Taking into account the fact that creativity and active participation are the important factors of motivation students in ESP learning, it is better to change routine exercises into the easy and entertaining ones that can help students both to remember new terms in the field of Civil Engineering and support students' creativity. Thus, we see prospects for further research in the construction of various forms and models of AVEI for the learning of English vocabulary in professionally oriented reading that contribute to the formation of lexical competence of students and enrich their technical knowledge. 


\section{REFERENCES}

1. Chernysh, V. V. (2010). Aktyvni metody u pidgotovtsi maibutnikh uchiteliv angliiskoii movy [Active methods of training future English teachers]. Rozvytok mizhnarodnogo spivrobitnytsva v galuzi osvity u konteksti Bolonskogo protsesu, Materialy mizhnar. nauk.-prakt. konf. (Yalta, 4-6 berezyia 2010 roku). Yalta: RVYZ Kryms'kii Gumanitarnyi Universitet, P. I.,122-125.

2. Dychkivska, I. M. (2004). Innovatsiini pedagogichni tekhnologii [Innovative pedagogical technologies]. Kyiv: Akademglav. https://eltutor.at.ua/Podskazki/Dychkivska.pdf

3. Knodel, L. B. (2008). Pedagogika vyshchoi shkoly: posibnyk dla magistriv [Pedagogy for a higher education institution: a guide for masters]. Kyiv: Vyd. PALIVODA A.V.

4. Rubtsova, S. V. (2018). Potentsial formuvannia u studentiv galuzi tsyvilnoi inzhenerii aktyvnykh metodiv navchannia dlia anglomovnoi leksychnoi kompetentnosti u chytanni [Potential of formation of English lexical competence in reading during active foreign language learning for students of civil engineering]. Naukovyi Chasopys of National Pedagogical Dragomanov University. Series 16, 30 (40), 69-75.

5. Smolkin, A. M. (1991). Metody activnogo obuchenia [Methods of active learning]. Moskva: Vysshaia shkola.

6. Ogle, D. (1986). K-W-L: A teaching model that develops active reading in expository text. The reading Instructor, 39, 564-570.

7. Robinson, Francis Pleasant (1978). Effective study (6th ed.). New York: Harper \& Row. ISBN 978-0-06-045521-7

8. Ministry of Education and Science of Ukraine. (2017). Standart vyshchoi osvity Ukrainy. Riven' vyshchoi osvity pershyi (bakalavrs'kyi) riven'. Stupin' vyshchoi osvity Bakalavr. Haluz' znan' 19 - Arkhitectura ta budivnytstvo. Spetsialnist' 192 - Budivnytstvo ta tsyvilna inzheneria [Standard of Higher Education of Ukraine for a graduate of the bachelor's level in the field of knowledge 19 - Architecture and Construction. Speciality 192 - Construction and civil engineering]. Kyiv: Vydannia ofitsiine. Retrieved from: http://mon.gov.ua/storage/app/media/vyshcha/naukovo-metodychna_rada/proekty_standartiv_vo/192budivnicztvo-bakalavr-22.09.2017

9. Pearson, P. D. (2007). Developing expertise in reading comprehension: What should be taught? How should it be taught? Technical Report No. 512. University of Illinois at Urbana-Champaign. Retrieved from: https://www.semanticscholar.org/paper/Developing-Expertise-in-Reading-Comprehension\%3AWhat-Pearson/cb6c9a93d5ad89632a916d6fle9f96872baa29a5

10. Zhang Fengjuan. (2010). The integration of the Know-Want-Learn (KWL) Strategy into English Language Teaching for Non-English Majors. Chinese Journal of Applied Linguistics (Bimonthly) Vol. 33 № 4 Aug. 2010.

11. Facing History and Ourselves. Retrieved from: https://www.facinghistory.org/resource-library/teachingstrategies/k-w-1-charts

12. Massey University of New Zeland. Retrieved from: http://owll.massey.ac.nz/study-skills/in-depth-reading.php

13. Toolshero platform. Retrieved from: https://www.toolshero.com/personal-development/sq3r-method/

14. Kwantlen Polytechnic University. Retrieved from: https://www.kpu.ca/sites/default/files/Learning\%20Centres/Study_SQ3R_LA.pdf

15. Rohana (2018). Method improving reading comprehension in primary education program students. Journal of Physics: Conference Series 954012027 doi:10.1088/1742-6596/954/1/012027.

16. Bigich, O. B. et al. (2013). Metodyka navchannia inozemnykch mov i kultur: teoria i pkaktyka. [Methods of teaching foreign languages and cultures: theory and practice]. Kyiv: Lenvit.

17. Rubtsova, S. V. (2021). English for Specific Purposes: English for Civil Engineering. Navchalnyi posibnyk [Textbook for bachelors]. Kyiv: KNUBA.

18. Rubtsova, S. V. (2021). Metodychni recomendatsii do navchalnoho posibnyka «English for Specific Purposes: English for Civil Engineering» [Methodical recommendations for the textbook]. Kyiv: KNUBA. 